\title{
THE EFFECT OF HALOTHANE ON THE LIVER OF DOGS EXPOSED TO MILD HYPOXIA ${ }^{1}$
}

Frank C. Haley, M D., and Gordon M. Wyant, F.F.A.R.C.s. ${ }^{2}$

Halothane was reported by Raventós in his original report (1) to have no hepatotoxic effects in animals when used in concentrations up to 1.2 per cent in arr or oxygen. The first clinical reports by Johnstone (2) made no mention of hepatotoxicity nor did those of Chang (3), Hudon (4), MacKay (5), Robson and Sheridan (6), and Abajian (7). A note of caution was sounded by Stephen et al (8). They reported that the chronic administration of halothane for a total of 24 hours spread over six days resulted in some central pallor in haematoxolin and eosin-stained sections of liver from dogs and monkeys. But they a so stated that in humans halothane was less likely than other anaesthetic agents to produce liver dysfunction. Hall, Geisler, and Norns (9) reported the case of a patient exposed to a large amount of halothane with only slight congestion of liver and kidneys revealed at post-mortem examination. They felt that the drug bad not contributed to the illness Little and Barber (10) reported that halothane affected hepatic function less than cyclopropane or ether anaesthesia Jones $e t$ al. (11) found halothane toxicity measured by intra-oesophageal instillation less than that of chloroform or divinyl ether, but greater than that of diethyl ether Stephen et al. (12) conducted toxicity studies in dogs and reported a mild hepatotoxic action which again was much less than that of chloroform.

This study was undertaken to elucidate whether the combination of halothane with an inhaled gas mixture slightly deficient in oxygen might reveal any latent viscerotoxic properties of the agent, not apparent in the presence of adequate oxygen Since mild degrees of hypoxia might occur during clinical anaesthesia for a variety of reasons, any significant effect of halothane under these conditions would markedly narrow its margin of safety.

\section{METHOD}

Four groups of mongrel dogs were studied. Each group consisted of six dogs weighing from 5 to $125 \mathrm{~kg}$ and groups were matched for weight. All dogs were premedicated with $15 \mathrm{mg}$ of morphine and $0.6 \mathrm{mg}$. atropine intramuscularly at least 20 minutes pror to induction of anaesthesia Induction was with 2.5 per cent sodium thiopental intravenously untıl the animals fell asleep, usually 25 to $30 \mathrm{mg}$. $/ \mathrm{kg}$ This was supplemented as requured with further thiopental while the dog was supme, the trachea intubated, a Silverman needle biopsy taken from the liver, and a femoral artery cutdown establshed. Mean arterial

\footnotetext{
1 Presented at the Western Division Meeting, Canadian Anaesthetısts' Socjety at Saskatoon, March 19-21, 1959

${ }^{2}$ From the Department of Anaesthesia, University of Saskatchewan and University Hospital, Saskatoon
} 
blood pressure was measured by means of a mercury manometer connected to the arterial cutdown ${ }^{-}$This system was flushed with heparinized saline from time to time.

Each dog was given 3 hours of inhalation anaesthesia. Those in the first group recelved halothane with 20 per cent oxygen and 80 per cent nitrous oxide. The second group received halothane in 100 per cent oxygen. The third group was given halothane in 15 per cent oxygen and 85 per cent nitrous oxide and the last group received 15 per cent oxygen and 85 per cent nitrous oxide alone. Nitrous oxide and oxygen were delivered from a McKesson anaesthesia machine to the endotracheal tube through a Fink non-rebreathing valve. Halothane was delivered from a Fluotec vaporizer with concentrations adjusted in such a way that the mean arterial blood pressure did not fall below $100 \mathrm{mg}$. Hg. This resulted in a mean concentration of halothane of 08 per cent. When respiration became depressed, it was controlled by means of a Stephenson ventilator. This was set to deliver $15 \mathrm{~mm} \mathrm{Hg}$ pressure at mhalation, no negative pressure being possible with a non-rebreathing valve.

At the conclusion of 3 hours of anaesthesia, a second needle biopsy was taken from the liver and the cutdown and endotracheal tube were removed. In most cases the dogs were struggling by this tume and were taken to the recovery cages. They were fed $a d$ lib. All animals in this series were alive and well next morning. At two and seven days postoperatively they were re-anaesthetized with intravenous thiopental and liver biopsies were taken.

The biopsy specimens were fixed in formaldehyde solution, embedded in paraffin and cut at $8 \mu$. Sections from all blocks were stained with haematoxylineosin and with PAS (periodic acid-Schiff method); some sections were alsa stained with Heidenhain's iron-haematoxylin.

The preparations were examined microscopically without knowledge of the treatment in each case, but the pre-anaesthetic specimen was known as such and served as normal control. It should be kept in mind that, owing to the procedure of needle biopsy, the architectural pattern of the specimens becomes distorted

From the aspect of the cell body in the haematoxyln-eosin preparation, in which most of the fat has been dissolved out by the embedding and straming procedures, the fat content was assessed and the sections graded in an arbitrary way $(+,++,+++,++++)$. Microphotographs reproduced in Figure 1 illustrate two different aspects, one from animal C-I, the other from animal C-6. It appears quite reasonable to state that in the paler cells more material has either been dissolved out or has not accepted the aqueous staining solutions. This material could be either fat or glycogen, or both. We believe we are justufied in assuming that the main substance responsible for the pale staming in the haematoxylin-eosin preparation is fat. This view is supported by an examination of alternate sections, that is sections from the same blocks, stained with PAS. If the paleness and vacuolization of liver cells in the haematoxylineosin preparation were caused by the loss of glycogen during fixation and stainng, the paleness and vacuolization in the haematoxylin-eosin preparation would be paralleled by a decrease of staining intensity in the PAS preparation. This 

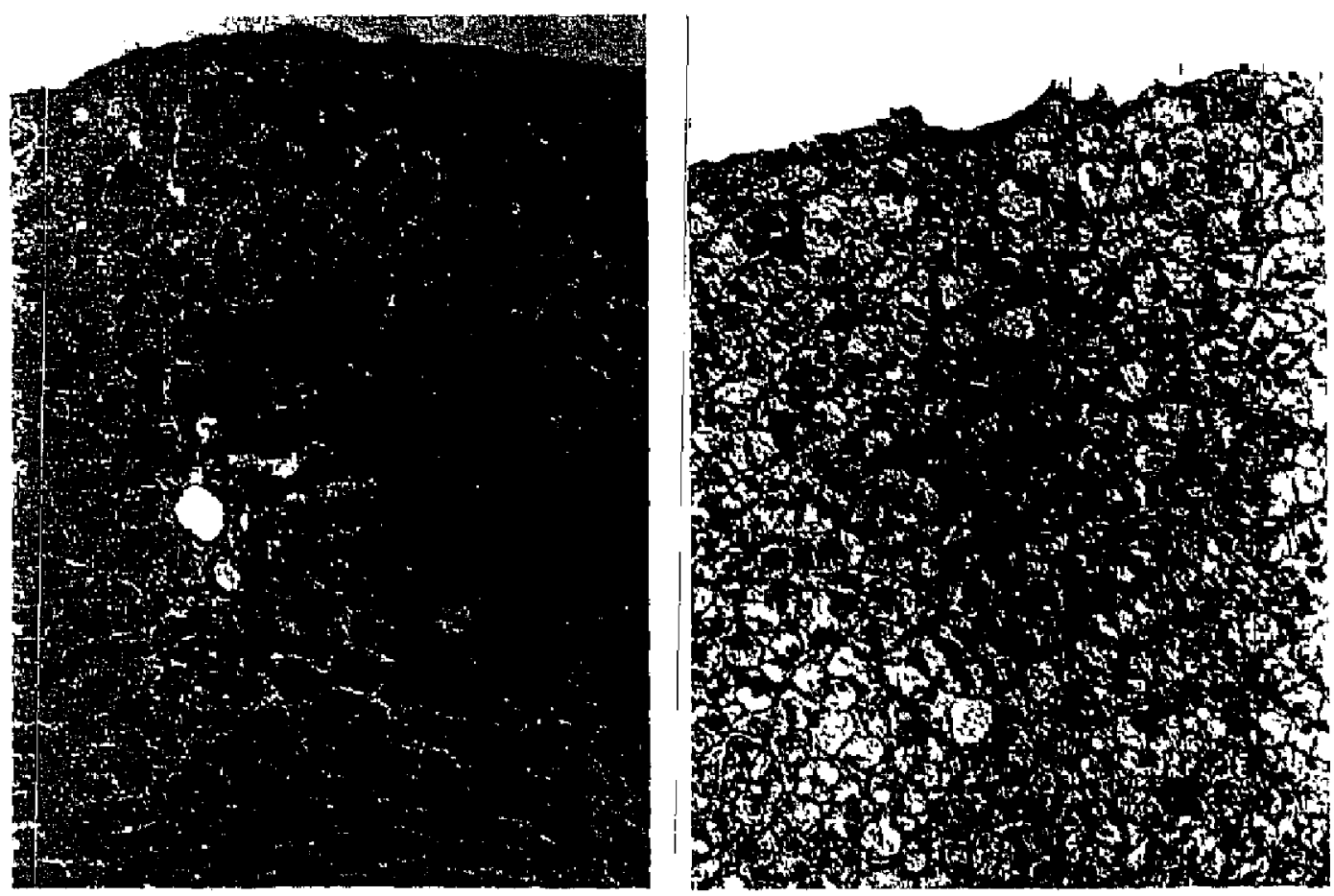

Fioure 1 Haematoxylin preparation of liver of animals No C-1 and C- $\theta$ (controls) Magnufication $\times 106$ Compare size of liver colls in the two figures as well is the intensity of stanning It is assumed (see tent) that the pale cells contain more fit than the dirker staming cells

was not the case and, therefore, it appeared safe to grade sections stamed with haematoxyln-eosin for morease or depletion of fat content, and sections stamed with PAS for glycogen content

We are aware that this procedure is not the most acurate The alternative was to fix half of each small specimen in formaldehyde soluton and stan frozen sections with Sudan IV or Sudan Black, whereas the other half of the specimen would have to be fixed m absolute alcohol, embedded in paraffin and stamed by Best's carmin method The disadvantages of these procedures on the small tissue fragments, many of which had become brittle "due to admuxed blood from unavordable haemorrhages outweigh, in our opunon, the advantages and the slight risk of misinterpreting small differences in fat and glycogen content

\section{RESULTS}

Comparisons were made difficult by the fact that, as might be expected, there was a marked variation in the fat and glycogen content between the various control liver specimens (Figs 1 and 2). Hence, any changes must be mterpreted as mcreases or decreases not from a common baseline but from the initial liver hustology of any particular anumal Futhermore, the proximity or otherwse of the last feeding and a varable amount of ingested food before biopsy may show 
up as mild changes in liver fat and glycogen. Hence, only marked differences between controls and later biopsies are significant.

The findings for fat and glycogen of the six animals $\mathrm{mn}$ each of the four groups are graphically shown in Figure 2. The inconstant changes, usually within a narrow range, indicate that halothane has no more toxic effect on the dog liver

Effects of Anaesthesia on Liver

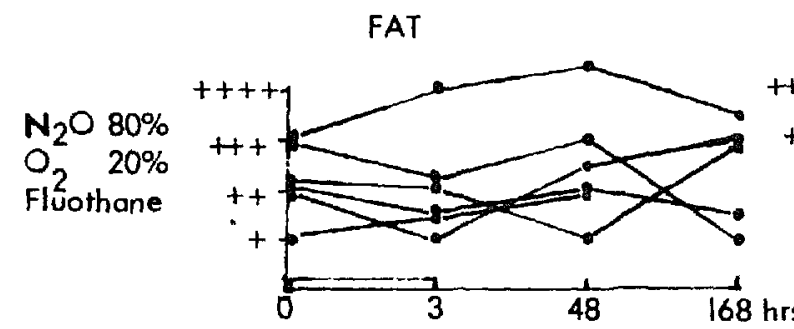

GLYCOGEN
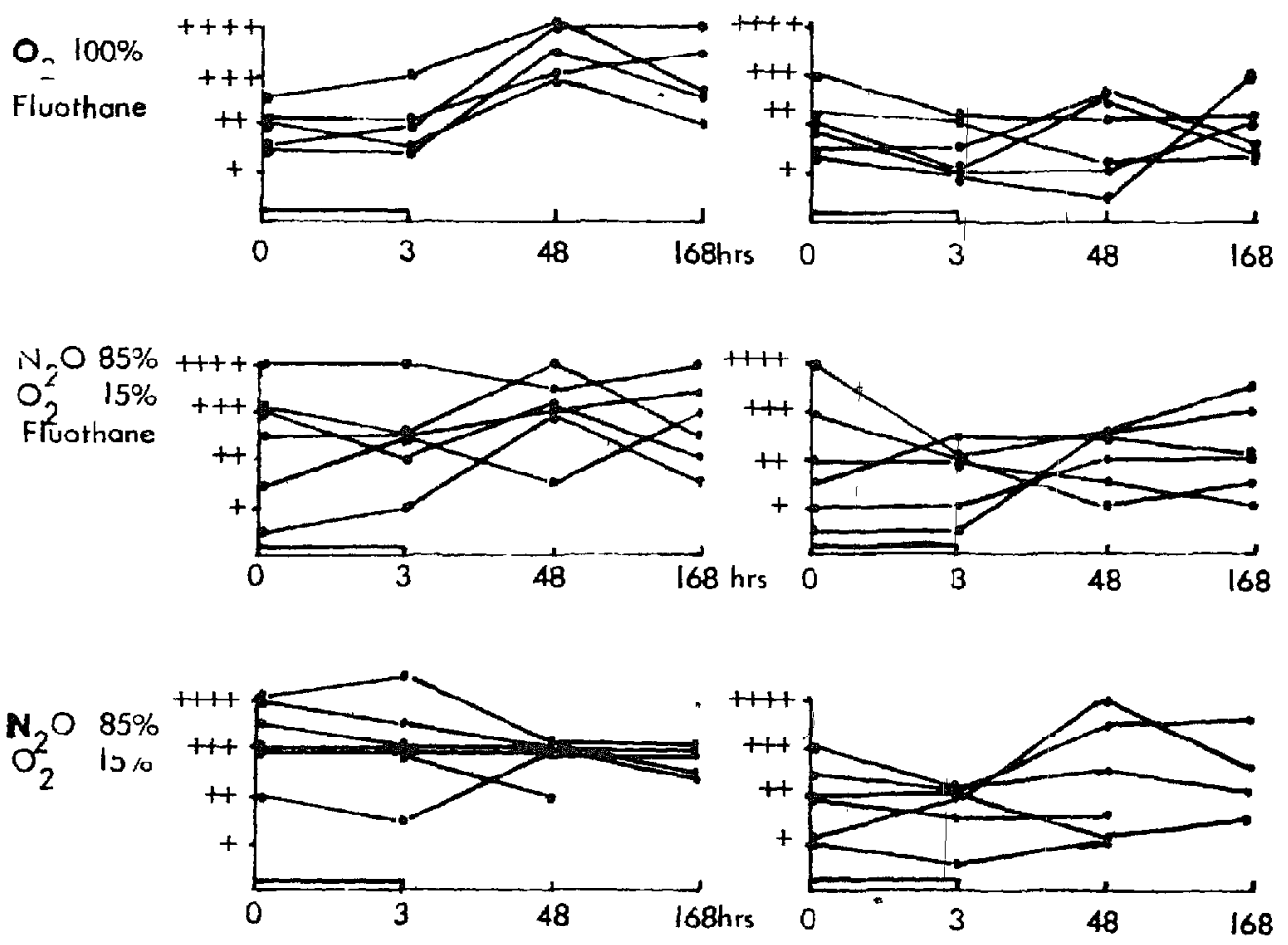

Figure 2 Summary of changes in liver fat and glycogen

when administered in a hypoxic atmosphere than has the inhalation of the slightly hypoxic gas mixture alone. Indeed, if any trend is apparent at all, it is in the series of halothane in oxygen in which there was a consistent increase in the liver fat content However, the average degree of this increase is still within the limits of normal variation and cannot be attributed therefore to the inhalation of halothane: 
Except for one specimen, where there was what appeared to be a.pathological vacuolization of hver cells, the body and nucleus of the parenchymal cells and of the sinusordal cells showed no changes indicative of serious damage

\section{Sumimary AND Conctusions}

Halothane has been shown to have no effect on the liver histology of dogs exposed to the drug for 3 hours while adequately ventilated. The agent has no adverse effect on liver fat, glycogen, and cellular structure even when it is administered in an atmosphere slightly deficient in oxygen.

\section{ACKNOWLEDGMENTS}

The authors are indebted to Dr. $\mathrm{R}$ Altschul, Professor of Anatomy, who made the sections and interpreted them $\mathrm{Mr} \mathrm{K}$. Drummond, a medical student on an Abbott Research Grant, assisted with the investigations.

\section{RÉSUMÉ}

Nous avons étudié quatre séries de sıx chiens chacune, chıens à poids égal deux à deux Chaque chien a été soumıs à une anesthésıe de trois heures. Un groupe a reçu de l'halothane avec 80 pour cent de protoxade d'azote et 20 pour cent d'oxygène et un autre groupe a reçu de l'halothane avec oxygène seulement. Un troisième groupe a reçu de 85 pour cent de protoxide d'azote et 15 pour cent d'oxygène sans halothane Nous avions pris, des biopsies hépatiques avant l'expérience et nous en avons pris d'autres immédiatement après, 24 heures plus tard et sept jours plus tard Sur les coupes, on a étudié les changements hépatiques en graisse et en glycogène Nous n'avons pas trouvé de changements importants et, en conséquence, nous pouvons conclure que, dans les conditions expérimentales données, l'halothane ne produrt pas de dommages sér1eux sur l'histologie du foie

\section{REFERENCES}

1 Riventós, J The Action of Fluothane A New Volatile Anaesthetic Brit J Pharm \& Chem $11(4) \cdot 394-409$ (1956)

2 Johnstone, $M$ The Human Cardiovascular Response to Fluothane Anaesthesia Brit J Anaesth 28 392-410 (1956)

3 Chang, J, McCartney, H H \& Graves, H B Clmacal Expenence with Fluothane A New Non-explosive Anaesthetic Agent Canad Anaesth Soc J 4(3) 187-206 (1957)

4 Hudon, F , Jacques, A, Clavet, M, \& Houde, J Observations cliniques sur l'anesthésie au Fluothane Canad Anaesth Soc J 4(3) 207234 (1957).

5 MacKay, I M Clinical Evaluation of Fluothane with Special Reference to a Controlled Percentage Vaporizer Canad. Anaesth Soc J. 4(3). 235-245 (1957).

6 Robson, J G, \& Sherman, C A Prelimmary Investigation with Fluothane Anesth \& Analg $36 \quad 62-74$ (1957).

7 Abajlan, J, Brazell, E, Dent, G, \& Mruls, E Preliminary Clinical Appraisal of Fluothane Anesthesiology 19(1) 93 (1958) 
8 Stephen, C R; Grosskreutz, D C, Lawrence, J H A, Fablan, L W, BoungeoisGavardin, M, \& Coughrin, J Evaluation of Fluothane for Clinical Anaesthesia. Canad Anaesth Soc J 4(3)-245-258 (1957)

9 Hal, Geisler, \& Norris Case Re zort Anesthesiology 19(1): 90-92 (1958)

10 Littise, D., \& Barbour, C Hepatic Function following Fluothane Anesthesia Work in Progress-Anesthesiology 19(1) 105-106 (1958).

11. Jones, W. M, Marcolis, G, \& STEPHEN, C. R Hepatotoxicity of Inhalation Anesthetic Drugs. Anesthesiology 19(6) 715-723 (1958).

12. Stephen, C R, Margolis, G, Fabian, L W, \& Bourgeols-Gavardin, M Laboratory Observations with Fluothane Anesthesiology 19(6) 770-'781 (1958) 